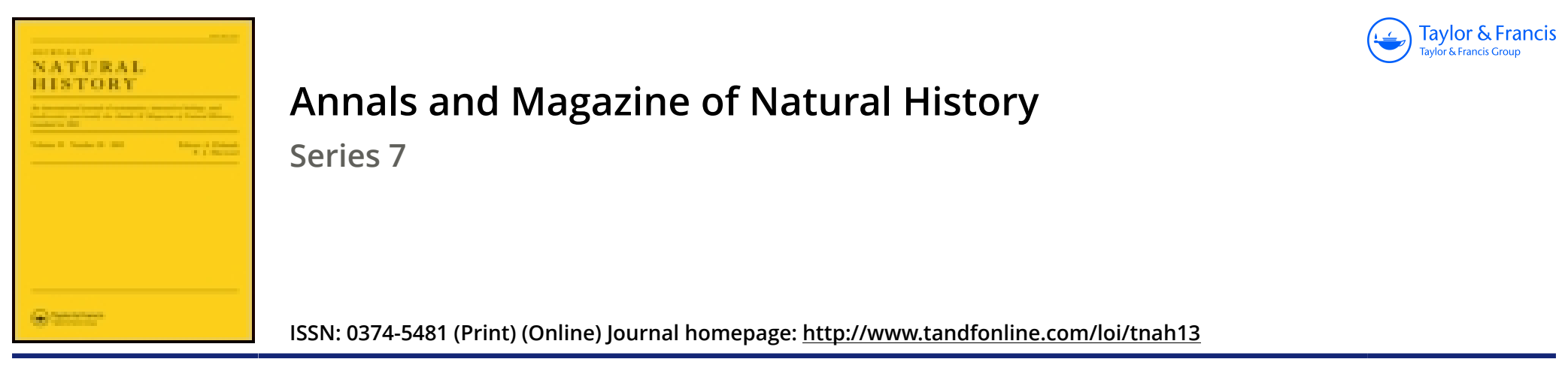

\title{
LXVII.-Description of a new species of African Hesperiinæ
}

\section{Hamilton H. Druce F.Z.S. F.E.S.}

To cite this article: Hamilton H. Druce F.Z.S. F.E.S. (1903) LXVII.-Description of a new species of African Hesperiinæ, Annals and Magazine of Natural History, 12:72, 636-637, DOI: 10.1080/00222930309487046

To link to this article: http://dx.doi.org/10.1080/00222930309487046

曲 Published online: 29 Sep 2009.

Submit your article to this journal

LII Article views: 4

Q View related articles $₫$ 
LXVII.-Description of a new Species of African Hesperiinæ. By Hamilton H. DRUCE, F.Z.S., F.E.S.

\section{Leucochitonea Hindei, sp. n.}

o.-Upperside. Allied to L. levubu, Walleng., from which it differs on the fore wing by broader black apical and outermarginal borders, containing differently placed white spots. The black apex extends irregularly almost to the wall of the cell. The second and third spots of the subapical series are shorter than in L.levubu, consequently this band has an irregular appearance. The black outer margin extends broadly to the angle and contains one more white spot than is usual in L. levubu, viz. two in the space between the lower median nervule and the submedian nervure. The marginal row of white spots which in $L$. levubu is composed of spots of almost uniform size, is in L. Hindei much more irregular, the apical four being small, the next two large, whilst the remaining two near the angle are again small.

The hind wing has the black margin slightly broader than in L. levubu.

The abdomen is white, with a broad black central stripe, the cilia chequered, the coxæ orange at the base, and the anal tuft black and white, as in L. levubu.

Underside. Fore wing as above. Hind wing as above, but with the costal nervure black from its base to its apex and a black basal suffusion between the anal margin and the submedian nervure. Antennæ black, whitish on underside of clubs. Legs black and white. Head black, with white spots.

9.-Differs from the male by having a thick anal tuft of Jellowish hairs, as in $L$. levubu o.

Expanse as in L. levubu.

Hab. Kitui, British East Africa (about 4000 feet) (S. L. Hinde).

This species, which I have named after its captor, Mr. S. L. Hinde, who took it in December $1900(3 \delta, 1 \%)$, is also allied to $L$, amneris, Rebel and Rogenhofer, described in Dr. Oscar Baumann's 'Through Massailand to the Sources of the Nile,' p. 338 (Berlin, 1894). L. amneris is described as being without the black veins of levubu, but with the black apical marking much broader and the "border spots" smaller and more rounded. It was captured in the Kiwaya Desert and at Umbugwe, which is south-west of Kilima-Njaro.

Mr. Hinde presented his specimens to the University Museum, Oxford, where the types now remain.

Plötz, in the 'Journal of the Entomological Society of Stettin,' 1885, p. 236, describes Sapcea lactea, but does not 
compare it with any other species, and gives as locality "Africa." He states it is figured in his Hesp. t. 857, which has never been published, and is now lost.

The description agrees, so far as it goes, with $L$. levubu, and in the British Museuin it is placed as a synonym of that species, with which I thoroughly agree. Dr. Holland does not mention it in his Revision of the African Hesperiidre (P. Z. S. 1896). Dr. Trimen (P. Z. S. 1891) writes of specimens of $L$. levubu from South-west Africa as having the black on the margins and nervules more developed than those from more southern tracts.

There is also a specimen in the Oxford Museum from the Loangwa Valley, Mushinga Mountains, British Central Africa, collected in August by Mr. C. H. Pemberton, and presented by Mr. C. V.A. Peel, which agrees exactly with the specimen in the same museum captured by the late F. Oates in Matabele Land in March, and referred to by Westwood in Oates's 'Matabele Land' (London, 1881, p. 335).

Rebel and Rogenhofer give the expanse of $L$. amneris as $35 \mathrm{~mm}$., while Plötz gives that of L. lactea as $19 \mathrm{~mm}$.

\section{BIBLIOGRAPHICAL NOTICES.}

J. H. Farre. Souvenirs Entomologiques (Huitième Série): Études sur l'Instinct et les Moour's des Tinsectes. Svo. Paris, 1903. Pp. 379.

Every few years this indefatigable observer of insect-life enriches our entomological libraries with interesting information, at first hand, on the habits and metamorphoses of various insects ; but it is only a short time since the first of his eight volumes was translated into English under the auspices of Dr. D. Sharp and Mr. F. Merrifield. We do not know if the serics is to be continued in English, but the latest volume of the original shows no falling off either in the interest of the anthor's observations, or in the vivacious and agreeable French sentimentality of the diction, which reminds ns of Alphonse Karr, and which forms so great a contrast to the humorous style of some of our English writers on similar subjects -Mr. E. H. Aitken, for example. So does the difference in national character show itself even in the style of popular books on natural history.

In his latest volume M. Fabre introduces us to Rose-Beetles; the beetles which destroy peas and beans; Pentatomas and Masked Bugs; Aphides and their enemies; wild bees (Halictus); carrionflies and beetles; wasps and Volucellce; and, finally, to various spiders whose nests are compared with those of the "Mésange Peuduline" (Penduline Titmouse).

There are some text-illustrations, chiefly representing eggs, cocoons, and nests, many of very elegant form, among the most curions being the eggs of Pentatomidx on 1.69. 